\title{
MANUFACTURE OF ACTIVATED CARBON SOAP FROM ARECA NUT SHELLS
}

\author{
E. Jayasathya, A.U.Santhoskumar \\ Department of Chemical Engineering \\ Dr. MGR Educational \& Research Institute University, \\ Chennai-95
}

\begin{abstract}
Adsorption is a widely used phenomenon in most fields, especially in purification and cleaning, using a wide variety of Adsorbents. Some commonly used adsorbents include Clay, silica gel, Activated Carbon, amongst them Activated Carbon is a widely used adsorbent because of its good force of adhesion to the impurities. Usage of activated carbon in cosmetics is a recently developing field, some of them include Activate carbon based Shampoo, Sun-tan creams, Toothpaste, Whitening Agents etc. One such kind of application is usage of Activated carbon for preparation of soap. Activated carbon is a well-known and widely used Adsorbent. Activated Carbon was prepared from finely powdered Areca nut shells, by activation with Phosphoric Acid at a temperature of $400^{\circ} \mathrm{C}$ and was tested for Adsorption properties. Small quantity of prepared activated carbon was used in the synthesis of the soap along with vegetable fat and base with some flavouring agents. The saponified fat matter with activated carbon was moulded and cooled to room temperature. Further the soap was tested for its composition, Alkalinity, Acidity, Moisture content etc
\end{abstract}

Keywords - Adsorption, Pathogenic repellent, Soaps, Areca nut shell

\section{INTRODUCTION}

In today's world more and more people are looking for natural solutions to some of the products they are using, especially when it comes to their body. As people begin to look towards natural products [1], as an alternative to commercial soaps with all their additives, more and more they are turning to natural soaps and looking for someone to supply them [2]. Hence we are preparing activated carbon soaps [3]. Activated carbon is a generic term used for a family of highly porous carbonaceous materials. Activated carbons have enormous surface area which makes them effective adsorbent [4]. The characteristics of activated carbon depend on chemical and physical properties and activation method. Agricultural waste is considered to be a very important feedstock for synthesis of activated carbon because of their renewable nature and lower cost [5]. As the cost of activated carbon is high [6], there is continuing research for sorbent which are cost effective and can be produced locally from agro-waste materials [7-10]. In the present investigation, the areca nut shell is used for synthesis of activated carbon and used it as an adsorbent. Areca nut consists of a hard fibrous outer covering commonly called husk enclosing within it the endosperm which is edible nut.

Activated carbon can be made from a variety of agrowaste materials by various activation methods. More recently, interest has been shown in the preparation of activated carbon using agricultural by-products as precursor material. This will reduce the importation of activated carbon therefore increasing the economic base. Several investigators have reported the composition, chemical characterization, and functional properties of agricultural waste [1-10].

The aim of the present investigation is production of activated carbon from areca nut shell and to study the activation process using phosphoric acid $\left[\mathrm{H}_{3} \mathrm{PO}_{4}\right]$ as activating agent. The activated carbon is prepared with varying ratio of composition of phosphoric acid and agro-waste. Cold processes soaps involves using lye or sodium hydroxide and water. Added to it are fats and oils, along with the range of different additives, all totally natural. Aloe Vera is popular as are coconut oil, fruits and vegetables as well as any number of natural herbs like lemon. Hot process of soap making simply involves using heat, in order to burn off excess liquid. When compared to other soaps, this activated carbon soap has high anti-bacterial activity. Thus forms less foams and also it remove oils and other stains.

The current study discusses about the preparation of activated carbon soap using Areca nut shell i.e. left outs of beetle nut after separation. The husk fibres of Areca Catechu (Areca Nut) are reported to be used by people of rural areas of Dakshina Kannada, Karnataka for cleaning their teeth. Literature studies show that the areca catechu shells are rich in antimicrobial properties, also act against some common pathogens. The paper presents a method of preparation of cost effective activated carbon Soap, the anti-microbial properties of Areca nut shells serves as good pathogenic repellent, thereby providing a good surface protection. 


\section{International Journal of Engineering Applied Sciences and Technology, 2020 \\ Vol. 4, Issue 12, ISSN No. 2455-2143, Pages 261-264 \\ Published Online April 2020 in IJEAST (http://www.ijeast.com)}

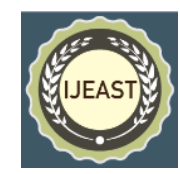

\section{MATERIAL AND METHOD}

Raw material used in this work is areca nut (of Indian origin). It is collected from the local field. Concentrated phosphoric acid (AR grade) procured from Fischer Scientific is used as an activating agent. Distilled water produced indigenously using Borosil double distillation unit is used for washing of the Activated Carbon after the activation process. $50 \mathrm{ml}$ of vegetable extract (fat), 10 gram of sodium hydroxide, $100 \mathrm{ml}$ of spring water, rainwater, distilled or demineralised water for preparation of the soda solutions, $2 \mathrm{~g}$ of activated carbon and $50 \mathrm{~g}$ of Aloe Vera and finally $\mathrm{HCl}$ is used for activate the carbon.

\section{Raw Material preparation}

The processing steps of preparation of feedstock (crushed hulls) from areca nut shell. Dried areca nut shells are manually broken in a traditional iron mortar pestle and the seeds are extracted. The areca nut shells are then broken; hulls (the stone type pericarp or hard shell of the seed) are separated from its internal soft part. The internal part is discarded as it is expected to have low adsorption capacity. The shells are washed with the distilled water and dried in an air oven (Universal make) at $100{ }^{\circ} \mathrm{C}$ for 3 hours The dried shells are crushed to smaller particles of size $\approx 3-4 \mathrm{~mm}$. Crushing is done in the roll crusher. Areca nut shell was used as the raw material for preparation of activated carbon. Areca nut shell was first washed with distilled water to remove dust particles and then dried at $110{ }^{\circ} \mathrm{C}$. The areca nut shells are then chopped into pieces of $1 / 4$ size in wide and $1 / 2$ long. Areca nut was crushed and sieved to about 180 mesh.

\section{Processing of activated carbon}

Preparation of activated carbon was done in three batch sizes of $50 \mathrm{gm}, 100 \mathrm{gm}$, and $300 \mathrm{gm}$. Phosphoric acid $\left[\mathrm{H}_{3} \mathrm{PO}_{4}, \mathrm{Merck}\right]$ was used as activating agent. A known mass of activating agent was mixed with distilled water; and areca nut shell was impregnated in acidic solution. The impregnated sample was kept for $24 \mathrm{hr}$. After $24 \mathrm{hr}$, the residual water was removed and kept in oven for $110^{\circ} \mathrm{C}$.

A weighed amount of impregnated samples were kept in muffle furnace for $400-650^{\circ} \mathrm{C}$. The activated carbon was subsequently removed from furnace and cooled to room temperature. Synthesized activated carbon was washed several times with distilled water until a $\mathrm{pH}$ range between 6 - 7 was obtained. The adsorbent is dried in an oven at $105{ }^{\circ} \mathrm{C}$ for a period of $24 \mathrm{hrs}$.

After activation of the samples, $3 \mathrm{M}$ hydrochloric acid $(\mathrm{HCl})$ was used to wash the samples. The washed samples were dried at $110{ }^{\circ} \mathrm{C}$ for $6 \mathrm{hr}$ in oven and then grounded to form carbon powder. Then the activated charcoal was used to soap production process.

\section{Operating method for the saponification process}

Weigh the quantities of raw materials (bleached vegetable fat and pre-melted and cooled to ambient temperature). Place them in a water heater or metal drum and heat to approximately $55-60^{\circ} \mathrm{C}$. Stop heating and add small quantities while stirring the soda solution. When the solution has emulsified, add the $10 \%$ soda solution. The temperature of the reaction mixture must raise to $100-120^{\circ} \mathrm{C}$. Adding the soda solutions to the mixture of oils cause the temperature to rise. Stir continuously and continue to heat gently for 2 to 3 hours and add aloe Vera paste in it. (Heals to restore and repair skin, refresh the skin, most beneficial if some kind of fungal skin infection)

Next, test the quality of the soap with a trowel. If the paste slides off in a block without leaving a trace, the saponification is completed. If, on the other hand, the paste leaves traces on the trowel, the saponification is incomplete.

Add the activated carbon already prepared by us. Continue to stir for a maximum of 5 minutes. Place the plastic sheet into the mould along the inner sides. Pour the saponified paste and cover it with the plastic sheet. Leave it to stand and dry for at least 72 hours. Remove the soap from the mould, cut it into pieces, mark or stamp as necessary.

\section{RESULTS AND DISCUSSION}

$$
\text { Pyrolysis Data Analysis (Yield Test) }
$$

Before pyrolysis was done, all the nine sampleswere first weighed using an electronic balance and the samples set to $103 \mathrm{gm}$. After pyrolysis and activation the samples were reweighed. In order to calculate the weight, the following formula was used;

$$
\begin{gathered}
\text { Weight loss }=\text { weight before activation }- \text { weight after } \\
\text { activation }
\end{gathered}
$$

From the table 1, it is evident that for a particular soaking time, weight loss in activation increased with increase in temperature. At lower temperatures e.g. at $460^{\circ} \mathrm{C}$, weight loss was relatively low. This could be because not all the volatile matter was driven.

\section{Percentage of yield}

The percentage yield was then calculated using the following formula; 
Yield $=$ Weight of Activated Carbon after Carbonization * $100 /$ Weight of the raw material

For example, a sample calculation at $460^{\circ} \mathrm{C}, 30$ minutes soaking time;

$\%$ Yield $=(103-38.74 / 103) * 100=62.388 \%$.

Soap Analysis

Estimation of Total Fatty Matter (TFM) Content of Soap

$5 \mathrm{gm}$ of soap was weighed accurately in a glass plate and transferred into a $250 \mathrm{ml}$ beaker and add $100 \mathrm{ml}$ of water was added to completely dissolve the soap. The mixture was heated directly till the fatty matter comes floating above. (Approximately 20-30 minutes).

Then concentrated $\mathrm{H}_{2} \mathrm{SO}_{4}$ was added to the beaker using a pipette carefully to the sides of the container until the fatty acids were floating as a layer above the solution. The volume of $\mathrm{H}_{2} \mathrm{SO}_{4}$ was noted.

The fatty matter collected was filtered using a filter paper and transferred to pre-weighed china dish. The contents were allowed to evaporate in an electric oven and the residue was weighed. From the difference in weight, the percentage of total fatty matter in the given soap sample was calculated.

\section{Calculations}

$$
\text { Weight of soap taken }=5 \mathrm{~g}
$$

Weight of filter paper $(\mathrm{x})=0.95 \mathrm{~g}$

Weight of filter paper - soap after drying $(y)=4.87-$ $0.95=3.92$

$\%$ of fatty matter $\quad=(\mathrm{Y}-\mathrm{X}) * 100 /$ weight of soap sample taken

$=4.87-0.95 * 100 / 5$

$=78.4 \%$

Total Fatty Matter in activated carbon soap $=\mathbf{7 8 . 4 \%}$

\section{Estimation of total alkali content of soap}

Weigh accurately about $5 \mathrm{gm}$ of soap and dissolve it in $150 \mathrm{ml}$ of hot water in $250 \mathrm{ml}$ beaker and exactly $40 \mathrm{ml}$ of $0.5 \mathrm{~N} \mathrm{HCl}$. Heat on a water bath until the fatty acid collected in a clear layer. Cool the beaker by placing in ice water.

For the cake of fatty acid and filtrate the liquid into a $500 \mathrm{ml}$ beaker leaving as much as possible fatty acid and thoroughly wash the beaker, fatty acid and filter paper with distilled water.

Combined filtrate and washing add phenolphthalein indicator and titrated the excess of acid with $\mathrm{NaOH}$ solution. Conduct a blank experiment taking $10 \mathrm{ml}$ of $0.5 \mathrm{~N} \mathrm{HCl}$. Calculate the amount of $0.5 \mathrm{~N}$ acid consumed in terms of $\mathrm{Na}_{2} \mathrm{O}$ and express percentage.

\section{Calculations}

Standardization of $\mathrm{NaOH} \mathrm{Vs} \mathrm{HCl}=19.5$

Standardization of $\mathrm{NaOH}$ Vs soap solution $=33.5$

$20 \mathrm{ml}$ of $0.5 \mathrm{~N}$ consumed $\mathbf{4 6 . 5} \mathrm{ml}$ of $\mathrm{NaOH}$

$$
20 \mathrm{ml} \text { of standard }(\mathrm{HCl})=33.5
$$

Acid used

$$
\begin{aligned}
& =\mathrm{A}-\text { volume of } \mathrm{NaOH} \text { consumed } \\
& \quad \text { for acid }
\end{aligned}
$$

Alkalinity $\quad=\left(3.1 *\right.$ acid used $\left.* \mathrm{~N}_{\mathrm{NaOH}}\right) /(1000$

$\%$ of $\mathrm{Na}_{2} \mathrm{O}=($ Alkalinity $/$ weight taken $) * 100$

$=(0.1873 / 2.99) * 100$

$\%$ of $\mathrm{Na}_{2} \mathrm{O}=6.9 \%$

Estimation of iodine value of vegetable fat

A $0.1 \mathrm{gm}$ of vegetable fat is weighed and transferred into iodine flask. To this flask, $15 \mathrm{ml}$ of chloroform and $25 \mathrm{ml}$ of hanus solution or mixture is added and warm slightly and is cooled for 10 minutes. Then the flask is allowed to stand for half an hour in dark place.

A $20 \mathrm{ml}$ of $15 \% \mathrm{KI}$ solution and $100 \mathrm{ml}$ boiled water (Hanus mixture) is added, cooled with distilled water and after that the solution is titrated against $0.1 \mathrm{~N}$ sodium thio sulphate solution until the appearance of yellow colour.

Again $1 \mathrm{ml}$ of starch indicator is added and is titrated against the sodium thio sulphate solution from the burette. Disappearance of blue colour indicates end point. The above procedure is repeated without taking sample (i.e. vegetable Fat) and the corresponding is noted for blank titration. 


\section{International Journal of Engineering Applied Sciences and Technology, 2020 \\ Vol. 4, Issue 12, ISSN No. 2455-2143, Pages 261-264 \\ Published Online April 2020 in IJEAST (http://www.ijeast.com)}

The saponification value of the vegetable fat sample was found to be $\mathbf{= 1 9 7 . 9 2}$

\section{Estimation of Acid Value of Oil}

Take 2 gm of vegetable fat is weighed and transferred it into $250 \mathrm{ml}$ conical flask. $50 \mathrm{ml}$ of $95 \%$ of previous neutralized alcohol solution (std. Solution) is added to the oil solution.

This mixture is heated for 10 minutes (till boiling starts) by using the heater. The solution is taken after 10 minutes and 1 or 2 drops of phenolphthalein indicator is added to it. Then this solution is titrated against the $\mathrm{NaOH}$ solution from the burette. After the titration is over, pink colour appears which indicates the end point.

Calculations

Standardization of potassium hydroxide

Normality of $\mathrm{NaOH}\left(\mathrm{N}_{2}\right)=0.1 \mathrm{~N}$

$1 \mathrm{ml}$ of $\mathrm{NaOH}$ solution $=4.0 \mathrm{mg}$ of $\mathrm{NaOH}$

Acid Value

$=[$ volume of $\mathrm{NaOH} *$ Normality of

$\mathrm{NaOH}^{*}$ Equivalent Weight*1000]/ weight of vegetable fat taken

$=(2.4 * 0.1 * 40 * 1000) /(2.01 * 1000)$

$=4.776$

The acid value of the vegetable fat sample was found to be 4.776

\section{CONCLUSION}

Thus from the above results we conclude that, the Activated carbon soap prepared from Areca nut shell has considerable moisture in comparison with other soaps, as referred Areca nut shell serves as a good antimicrobial agent. Activated carbon serves present in the soap is well distributed and on application forms lather that bind with the dust and impurities there by complete removal of stains, and with good moisture once washed off.

Usage of naturally available raw materials and less amount of base is the preliminary factor for the good quality of the soap. Though there some Activated carbon soaps commercially available in market, the one produced in our study is cost effective and skin friendly. Our soap accepted the aloe Vera properties used as an anti-bacterial agents, and also it improves and maintain the moisture and glowing to the skin.
Commercially available soap contains, sodium lauryl sulphate, fillers and whitening agents but the prepared activated carbon soap does not contains any such toxic chemicals and also our soap contains about $78.4 \%$ of Total Fatty Matter (TFM). Thus being environmentally safe.

\section{REFERENCE}

[1] Sunanda Tiwari, Sapindus Based Activated Carbon by Chemical Activation. Chemical Engineering Department, DCR University of Science and Technology, Vol.1, pp 9-15, 2013

[2] Tanstia., Project profile on Activated Carbon. Prepared by coco shells - FNF service centre. Vol.4 pp.1-12, 2003

[3] A.S. Jadhav, Carbon - Science and Technology, Synthesis and characterization of chemically activated carbon derived from arecanut shell, Department of Chemical Engineering, AISSMS College of Engineering, Vol 8, pp (3239), 2004

[4] MN Mohd iqbaldin, Properties Of Coconut Shell Activated Carbon, Vol 25, pp 497-503,2006

[5] Gopal, Activated Carbon Preparation, Metroblue Industries P.B., pp (24-37), 2008

[6] Kirmada, Preparation and characterization of Activated Carbon from apple waste by microwave - assisted Phosphoric acid activation. Vol.8, pp 513-3022,2013

[7] HattiangdV William, Some Physical Chemical Properties of Aqueous Solutions of Soaps and Soapless Detergents. pp 120,2011

[8] Sana Ahamed, Study of Physical and Chemical Properties of Neem (Azadirachta indica), Vol.7, pp.239-242,2015

[9] SM Abd El Salam, Improved technique for hand-crafted soaps and detergents production by Martial Gervais Oden Bella, COLLECTION PRO-AGRO,2013

[10] N.M. Abd El-Aziz, Physical and chemical characteristics of toilet soap made from apricot kernel oil, pp. 24-35,2013

[11] .Johansson, Procedure to determine pentosan content present in various soft and hard woods by using hydrochloric acid and furfural, vol.2, pp.1-10,2014

[12] Thesis report, Comparative studies on the aging of thermally upgraded paper insulation in palm fatty acid ester, mineral oil, and natural ester, 2017. 